\title{
A Heretic from a Good Family? A New Look at Why Levi b. Abraham b. Hayim Was Hounded Tamar Ron Marvin
}

\begin{abstract}
Levi b. Abraham b. Hayim, a popularizer of rationalist philosophy active around 1300 in Occitania, was identified as a transgressor by proponents of a ban on the study of philosophy. The nature of Levi's transgressive activities and the reasons why he was targeted have remained elusive, though a consensus view suggests that his socioeconomic standing and genuinely radical ideas contributed to his being singled out. In fact, a careful reassessment of the extant sources demonstrates that Levi, as an established member of the elite class, was an inadvertent target, identified in the course of a misunderstanding between Solomon Ibn Adret and his confidant in Perpignan, Crescas Vidal. No more radical than others and one of many popularizers of rationalism, Levi became a convenient exemplar and test case for ban proponents. They struggled to define the nature of Levi's potentially dangerous effects on his students, however, and Levi remained an equivocal figure even to his detractors. Though vilified and forced out of the home of his patron, Levi was accorded basic respect and often defended; he was never subject to excommunication, censure, or any type of halakhic prosecution.
\end{abstract}

\section{INTRODUCTION}

An otherwise unremarkable member of the educated class in medieval Perpignan, Levi b. Abraham b. Hayim (c. 1245 - c. 1315) was an established middle-aged scholar and teacher when he was targeted as a transgressor by proponents of a ban on the underage study of non-Jewish philosophy. A man "hated by many," Levi was likened to "a high priest turned Sadducee" and accused of "destroying the Torah with a hatchet"; his magnum opus, a Hebrew philosophical encyclopedia, was called a dangerous "book of sorcery.", Levi was the only

I wish to thank Benjamin R. Gampel, Raymond P. Scheindlin, Eitan P. Fishbane, James T. Robinson, and Joel Kaye for their insightful feedback on the research upon which this article is based, and the anonymous reviewers of this article for their helpful suggestions.

1. These descriptions come from the letters preserved in the compilation Minhat kena'ot. Minhat kena'ot has been printed in two editions in the modern era, once in Pressburg in 1838 by Mordecai Leib Bisliches (under the approbation of the Hatam Sofer) and again in Jerusalem in 1991, edited, annotated, and with a critical apparatus by H. Z. Dimitrovsky. The Pressburg text has been reprinted in whole or in part several times and is based on a lost manuscript; Dimitrovsky's apparatus includes all eight extant manuscripts. Here, the Pressburg edition is abbreviated MQp, and the Dimitrovsky edition MQd. References are given as edition, chapter, page number, and, for MQd, line numbers. Unless otherwise noted, my translation follows Dimitrovsky's critical text.

Respectively, these unflattering and accusatory descriptions of Levi occur in MQp 12, p. 47 / MQd 30, p. 367, 1. 38; MQp 12, p. 46 / MQd 30, p. 365, 1. 6; MQp 14, p. 51 / MQd 32, p. $370,1$. 79; and again MQp 12, p. 46 / MQd 30, p. 365, 11. 4-5. 


\section{Tamar Ron Marvin}

distinct individual accused of heretical impropriety in the course of the acrimonious 1304-6 conflict over the study of non-Jewish philosophy, the capstone of some one hundred and twenty-five years of discussion and debate about the integration of Greco-Islamic rationalism into traditional Jewish thought initiated by the work of Maimonides. Despite ban proponents' strident disapproval of Levi, their unarticulated and unlegislated definition of transgression based in ideation prevented his persecution; moreover, it was not his detractors' intention to single out individuals for censure in the first place.

The events surrounding the accusation of Levi are recorded in a series of letters that are preserved in the compilation Minhat kena'ot, edited by Montpellier intellectual Abba-Mari b. Moses ha-Yarhi (fl. c. 1300). A plurality of the letters in the compilation are authored by Abba-Mari and Solomon b. Abraham Ibn Adret (Rashba, c. 1235 - c. 1310), including "corporate" letters, mostly composed by Abba-Mari or Ibn Adret, from the Montpellier kahal or the Barcelona kahal-in reality, a small segment of the elite community members who supported the effort. ${ }^{2}$ Only a handful of letters among the approximately one hundred in the compilation directly regard Levi; ${ }^{3}$ they occur in its first third, meaning that they were written in the late summer and early fall of $1304 .{ }^{4}$ Levi was never formally excommunicated or, it appears, bothered again for the remainder of the controversy, which continued another two years before it was abruptly halted by the French general expulsion (and attendant waves of expulsion) beginning in 1306. Levi was accused only to become quickly irrelevant to the disputants, if not before they created difficulties for him.

\section{Equivocal Accusations}

Why was Levi hounded, to borrow the wording of A. S. Halkin's influential exculpatory 1966 article? ${ }^{5}$ What exactly was Levi accused of doing - and why was he never formally prosecuted for it? The words of Levi's detractors are marked by their incoherence: they are imprecise, emotional, equivocal. These

2. Minhat kena'ot also includes a variety of other voices from communities in Occitania and Iberia, mostly those of supporters of the ban efforts, though it is worthy of note that Abba-Mari pledges at one point to compile an analogous anthology of the letters of his opponents: MQp 97, pp. 176-77 / MQd 117, p. 824, 11. 1-8.

3. Because Minhat kena'ot includes a theological introduction by Abba-Mari (numbered sequentially in MQd), nonletter chapters, letters broken up or combined into a chapters, and accretions of noncontemporary documents at the end, the letter count is inherently subjective.

4. Few of the letters are dated, but enough explicit and relative dates are given that it is possible to reconstruct an approximate timeline of events. The first date given, 29 Elul, occurs in MQp 19 / MQd 37, while the year 5064/1304 is first mentioned in MQp 21 / MQd 39. Because Abba-Mari, in his editorial notes, mentions a break in correspondence between Sukkot and the first letters dated to 1305 (MQp 60 / MQd 69), this places the letters surrounding the accusation of Levi in August-September 1304. The latest mention of Levi occurs in MQp 42, pp. 93-96 / MQd 61, pp. 537-48, Ibn Adret's response to Samuel b. Reuben's defense of Levi, a close relation.

5. A. S. Halkin, "Why Was Levi ben Hayyim Hounded?," Proceedings of the American Academy for Jewish Research 34 (1966): 65-76. Halkin posited that Abraham was targeted because of his low socioeconomic status vis-à-vis his colleagues; see discussion below. 
are not the formal proceedings of a tribunal or even of a carefully considered responsum. In large part this ambivalence derives from the characteristics of medieval epistolary practice and, more broadly, literary culture. The nature of medieval Hebrew belletristic writing, to which the Minhat kena'ot letters belong in terms of form, is figurative, ornamental, and oblique. The letters are not circumspect; quite the opposite, they are often bombastic, the accusations flying like the swords to which they are metaphorically compared by the authors themselves. ${ }^{6}$ But the authors' words are indirect, leaving the crux of the problem unarticulated, as though it were obvious, and identifying it unbecoming. As a result of this literary posturing, there is a marked lack of clarity in the language with which Levi was accused.

The first time Levi appears in the text of Minhat kena'ot, in a report written by Crescas Vidal in Perpignan to Ibn Adret in Barcelona, Crescas describes him as misleading the impressionable - without stating that Levi necessarily intended or perpetrated any distinct ill. Crescas Vidal's equivocal report to Ibn Adret reads:

Now I'll tell you noble men what I know and what I've heard about the man, Levi, whom we mentioned. Naturally, I saw him in the land of Provence and found that his heart is as great as the sea, that he is knowledgeable in the Talmud and involved in its study. For he learned it [Talmud] from his youth and became cunning, ${ }^{7}$ and none could compete with his knowledge and intelligence, except those who knew him and were his peers. When he spoke with a man whom he knew was not learned in the Torah of God and in the words of our holy sages, his [Levi's] heart was emboldened and he was able to deceive him without the man discerning whether he was an evildoer or whether his teaching was pious. I attempted many times to get him to show me his book, but he would defer me, saying that he didn't have it with him in his residence. ${ }^{8}$

6. In several places in Minhat kena'ot the act of writing a letter is described using the trope of "girding oneself with words" as one would with a sword, familiar from Hebrew literary conventions. Among many, examples include: Abba-Mari in his general introduction, "Because of these [transgressions], my heart shall wield the sword of rhetoric" ('al ken libi herev ha-melizah yenofef, MQp intro., p. 3 / MQd intro., p. 226, 1. 15); Abba-Mari in his initial letter to Ibn Adret, "Gird your sword upon your thigh ... and let it be the sword of your rhetoric [herev melizatkha], flashing in the faces of the scholars of this land" (MQp 1, p. 20 / MQd 19, p. 273, 11. 44-47); and referring to Ibn Adret, "the Rabbi girded his rhetoric upon his thigh" (hagar ha-rav melizato 'al yarekh, MQp 10, p. 44 / MQd 28, p. 359, 1. 3-4). Based on biblical precedent (e.g. Judges 3:16, in which Ehud girds his double-edged sword beneath his clothing and uses it in a surprise attack on the king of Moab), rhetoric as swordplay is a trope that appears in medieval Hebrew poetry.

7. The word 'arum, which I have translated as "cunning," generally carries a negative connotation; it is not just subtlety or cleverness, but cunning used for deception. However, Dimitrovsky suggests that it is here used in the positive sense of subtle, careful speech, citing the rabbinic discussion in B. Pesahim 3a, which uses Job 15:5, "Your own mouth condemns you, not I; your lips testify against you," to argue (paradoxically) for the importance of care and purity of speech in all matters. However, it seems to me that Crescas is making a point about Levi's power of persuasion: he explains that he was able to mislead many precisely because he was learned and clever.

8. MQp 12, p. 47 / MQd 30, p. 369, 11. 55-62. 


\section{Tamar Ron Marvin}

If Crescas readily admits that Levi was a talented Talmud scholar, he appears to do so mostly in order to point out that Levi's actions are all the worse because he committed them knowingly. This type of backhanded compliment accords with the halakhic principle that places more weight on intentional transgression, especially transgression that takes place after receiving a warning, rather than acts committed due to ignorance. Crescas implies that Levi knew he was pushing the envelope; that is why, Crescas suspects, Levi claimed that he did not have a copy of his own book on the many occasions that Crescas says he asked. Still, Crescas's report is hardly a strong indictment of Levi. While it depicts Levi as a suspicious, deceptive character, it also defends his background and stresses his scholarly abilities.

In fact, Crescas reports that he was surprised when others in Perpignan told him of Levi's improprieties. He nevertheless reports these allegations to Ibn Adret: "Others told me, however, that this Levi destroyed the covenant, making figurations out of the writings on the act of creation." According to this report, Levi propounded an allegorical interpretation of Genesis incompatible with traditional exegesis. Crescas states that he then sought the opinion of Samuel ha-Sulami (d'Escaleta, fl. c. 1300), a leading Occitan intellectual who boarded Levi in his home and thus not surprisingly defended Levi's uprightness: ${ }^{10}$

9. Gregg Stern suggests that zurot is a Hebrew translation of the technical Latin term Figurae; I have followed this suggestion in my translation. See his "The Crisis of Philosophical Allegory in Languedocian-Jewish Culture (1304-6)," in Interpretation and Allegory: Antiquity to the Modern Period, ed. Jon Whitman (Leiden: Brill, 2000), 195-96.

10. There is some confusion about the identity of Samuel ha-Sulami, in particular about the origins of his place-name and his relationship to another prominent Occitan Jew bearing a similar name. Many towns have been nominated for Escaleta, from Iberia to central France, and numerous variations of d'Escaleta occur, including d'Escalita, de l'Escalette, Sescaleta, and others, morphing into d'Escola, Sescola, and other variations - which, unlike Escaleta, which was Hebraized semantically as sulami on the analogy of "ladder," would be Hebraized semantically as kenesi on the analogy of "school," as in the fourteenth-century Occitan astronomer Samuel b. Simon ha-Kenesi / Astruc d'Escola. In addition, there are contemporary records of a Samuel Sekili in Narbonne - whose daughter was married to Crescas Vidal's son; see Gregg Stern, Philosophy and Rabbinic Culture: Jewish Interpretation and Controversy in Medieval Languedoc (New York: Routledge, 2009), 154-56. It has been argued that Sekili was an alternate name for ha-Sulami. It has also been argued that Sekili was a different individual. Most sources on ha-Sulami return to the research of Heinrich Gross, Gallia Judaica: dictionnaire géographique de la France d'après les sources rabbiniques, trans. Moïse Bloch (Paris: L. Cerf, 1897; rprt., with supplementary material by Simon Schwartzfuchs, Amsterdam: Philo Press, 1969), 430-31, and Ernest Renan, "Les Rabbins français du commencement du XIVe Siècle," in Histoire Littéraire de la France 27:430-734 (Paris: Imprimerie nationale, 1877), 700701; and see also Yitzhak Baer, A History of the Jews in Christian Spain, trans. Louis Schoffman, 2 vols. (Philadelphia: Jewish Publication Society, 1992), 1:292.

What is known definitively about Samuel ha-Sulami is that he was a prominent intellectual: a poet, talmudic scholar, and well-versed philosopher. He is identified as such by the fifteenth-century intellectual Jacob Provençali (in his "Responsum on the Matter of Studying the Sciences," in Sefer divrei hakhamim, ed. Eleazar Ashkenazi [Metz, 1849], 70) and by Menahem ha-Me'iri (in Simon b. Joseph, Hoshen ha-mishpat, printed in David Kaufmann, ed., "Simeon B. Josefs Sendschreiben an Menachem B. Salomo: Ein Beitrag zur Geschichte der Jüdischen Exegese und Predigt im Mittelalter," in Jubelschrift zum Neunzigsten Geburtstag des Dr. L. Zunz, Heb. sec., 143-51 [Berlin: Louis Gerschel, 


\section{A Heretic from a Good Family?}

When I reported these things to the scholar ha-Sulami he replied, "This is nothing other than gossip, for I have seen him to be exacting in every fine detail of the text, praying the evening and morning services, and walking in the path of the good and the way of the righteous. If he should be found to be transgressive and guilty in even one of those matters, he will have no monument and name in my house and within my walls."11

Crescas continues, still equivocal:

If people should appeal to our lord [ha-Sulami] about this man [Levi], well, you have seen with your own eyes that one person denigrates him while the next person exalts him. Admittedly, I have heard bad things about himthat it is his decision and his practice to teach the books and language of the Chaldeans [i.e., philosophy of Greek origin] ${ }^{12}$ to anyone who hired him, because he had fallen on hard times, whether he [the student] be an old, elderly man or a fledgling who just left the nest. ${ }^{13}$

Crescas is at pains to emphasize that popular opinion about Levi is mixed. He reports a simple, even banal, explanation for Levi's indiscriminate teaching of philosophy: Levi needed the money. Crescas's conclusion is that Levi may conduct

1884], 163). On Provençali's citation, see Susan L. Einbinder, No Place of Rest: Jewish Literature, Expulsion, and the Memory of Medieval France (Philadelphia: University of Pennsylvania Press, 2009), 33-34. In addition, it is reasonably conjectured that ha-Sulami was a moneylender by profession, and he lived primarily in Narbonne. Richard Emery's research in the Perpignan archives is, in fact, dominated by two Jews engaged in mercantile activities, one of whom is Salamon Sullam da Porta (and variations, e.g. Samiel Sullam, Solam da Porta). This same financier is to be found in Latin documents from Aragon, which place his birthplace (or family center) at Villefranche, from where Levi b. Abraham hailed. The records, furthermore, place Samuel's principal place of residence at Narbonne, not Perpignan. See Richard W. Emery, The Jews of Perpignan in the Thirteenth Century: An Economic Study Based on Notarial Records (New York: Columbia University Press, 1959), 17-19. This is supported by a responsum unrelated to the controversy, regarding devalued coinage, which was addressed to ha-Sulami in Narbonne by Ibn Adret (cited by Renan and preserved in MS Bodl. 781, Oxford and published by Aharon Zaleznik, ed., She'elot u-teshuvot ha-Rashba ha-hadashot mi-ketav yad [Jerusalem: Mekhon 'Or Ha-mizrah, 2005], 46, no. 74); discussed by Pinchas Roth, "Regional Boundaries and Medieval Halakhah: Rabbinic Responsa from Catalonia to Southern France in the Thirteenth and Fourteenth Centuries," Jewish Quarterly Review 105, no. 1 (2015): 84-85. Ha-Sulami is assumed to have been living in Narbonne at the time of the controversy, when he boarded Levi. As to his birth date, Gross identifies ha-Sulami in a manuscript dated 1255, which suggests that he was born around 1235, making him a contemporary of Ibn Adret and Jacob b. Makhir. This accords with Emery's findings as well.

11. Though styled as a direct quotation, ha-Sulami's statement is clearly elevated by Crescas for rhetorical purposes, as the high register and density of biblical allusions in it reveal.

12. In the context of rabbinic literature, "Chaldeans" usually refers to Greeks, but here the term seems to be more broadly applied. Crescas most likely means that Levi was teaching Greco-Islamic philosophy in Hebrew translation.

13. MQp 12, pp. 47-48 / MQd 30, pp. 369-70, 11. 62-70. 


\title{
Tamar Ron Marvin
}

himself inappropriately at times, but he does not brand him categorically a transgressor.

Even Ibn Adret's assessment of Levi, in response to Crescas's reports, was nuanced. Ibn Adret considers Levi to be a contemptible character, though not beyond rehabilitation. Ibn Adret baldly replies to Crescas: "Not a few people have told us about the defects of this man Levi ... even if, as he [Samuel ha-Sulami] recently attested, that he [Levi] goes to the synagogue evening and morning, and privately agrees with the precepts of the Torah." ${ }^{14}$ Crescas was apparently not the only person whom Ibn Adret consulted about Levi, and by the time Ibn Adret wrote his reply to Crescas, his mind was made up. Regularly attending to prayer does not a pious man make, Ibn Adret admonishes Crescas. In his following letter, addressed to ha-Sulami, Ibn Adret gives a few more details about the reports he received from others:

\begin{abstract}
Do not try to claim that this is the slander of secret informers, for it is placed in their mouths ${ }^{15}$ and they don't say it in secret, nor do they whisper it in one's ear and under concealment. Those who break bread at your table tell of your uprightness and the righteousness of your behavior, yet they insist on this bad situation [with Levi]; in fact, they speak of it with raised voices.... Concerning this [the travelers' reports], excepting [what they say about] your fine reputation, I do not suspect malice in their words, because those who provide the reports come one after the other, more and more of them, and it can be assumed that they [the reporters] do not know one another and come at random times - surely they can't all be lying. ${ }^{16}$
\end{abstract}

Even assuming some exaggeration on Ibn Adret's part, it appears that he was impressed by the consistency and vehemence of the reports he received about Levi. Moreover, the people he spoke with roundly portrayed ha-Sulami himself as an upstanding person, something Ibn Adret already knew and that served to confirm his hunch that these travelers were being honest in their assessments. He accepted their reports that Levi was imprudently spreading knowledge of nonJewish philosophy - though again, not flagrantly violating Halakhah.

Implicit in Ibn Adret's assessment of Levi is his view that it is immaterial whether Levi agrees with the words of the Torah in private (be-seter), as Ibn Adret wrote to Crescas. If private belief cannot save Levi from suspicion, then, in Ibn Adret's view, overt transgression cannot be marked by private disbelief either-at least for the purposes of the community. Ibn Adret echoes this in his letter to Levi: "Why should we descend into controversy that upends regional boundaries just because some man believes whatever his heart desires? Because he comes out publicly, as he wishes, with this heresy and becomes a heretic [ba'al minut liheyot min]. ${ }^{17}$ Improper ideation that is merely private and never

14. MQp 14, p. 51 / MQd 32, p. 380, 11. 82, 84-85.

15. I.e., they are compelled to report what they know to be true.

16. MQp 15, p. 53 / MQd 33, p. 389, 11. 44-50.

17. MQp 16, p. 54 / MQd 34, p. 391, 11. 19-20. 
disseminated does not warrant communal conflict. At the same time, from Ibn Adret's earlier remark (in the letter to Crescas) that punctilious prayer does not absolve Levi of the accusation of transgression, it would seem that Ibn Adret does recognize and esteem the importance of private belief. ${ }^{18}$ After all, if acting appropriately - going to synagogue for regular prayer - does not alone testify to a person's uprightness, then his motivation for and beliefs about performing the action must bear significance. In light of this, it is necessary to distinguish between the pragmatic delineation of ideational transgression that Ibn Adret proposes for the purpose of instituting a ban, and his more complex understanding of what constitutes correct belief and behavior.

For the purposes of confronting legislatively dangerous ideas, it is thus not private belief (or disbelief) that primarily concerns Ibn Adret, but rather the dissemination of the allegorical interpretation of Scripture as Scripture's true deeper meaning in contradiction to the rabbinic interpretation. It is for this alleged act that Ibn Adret levies upon Levi the curse yimah shemo ve-zikhro"may his name and memory be obliterated," a conventional curse most often applied by medieval Jews to Jesus. ${ }^{19}$ Ibn Adret charges Levi:

You are a learned man; I saw your pamphlet [kuntresekha], which collects honey from the carcass of a lion. ${ }^{20}$ You claim that you have written good, lifesustaining words. If only it were so. ... You taught and wrote and interpreted as you saw fit, but after you entered [into Torah study], why did you leave it? ${ }^{21}$ Maybe if you applied yourself as you did in the beginning, you would

18. In MQp 14, p. 51 / MQd 32, p. 380, 11. 82, 84-85. Cf. Maimonides, Mishneh Torah, Sefer 'ahavah: hilkhot tefillah 10:1.

19. MQp 14, p. 51 / MQd 32, p. 381, 11. 97-99. Specifically, Ibn Adret curses Levi because Levi reportedly taught that Abraham and Sarah rotted away after death, in contradiction to rabbinic traditions as codified in B. Bava Batra 17a. However, Ibn Adret addresses this remark about Levi to Crescas Vidal, not Levi himself, whom he approaches with lesser bile. Though he admonishes Levi sternly - "You should wonder why I haven't yet ascended a steep mountain with a shofar strapped to my chest and blasting-trumpets in my hands, shouting in writing and aloud," Ibn Adret writes to Levi (MQp 16, p. 54 / MQd 34, p. 392, 11. 30-31) - this hardly approaches the sting of "may your name be obliterated." Ibn Adret also addresses Levi as a fellow gentleman and a man of intelligence. In fact, this is part of the reason for Ibn Adret's ire: that Levi should know better.

The conventional curse Ibn Adret levies upon Levi in the letter to Crescas is abbreviated as yesh" $u$. It should be emphasized that Ibn Adret says this conditionally: if indeed Levi is responsible for what his detractors claim he has done, he should be so cursed. Compare this to Ibn Adret's harsh words about a convert to Christianity, whom he identifies only by the rabbinic epithet of anonymity, ploni, in his letter to Samuel ha-Sulami. There Ibn Adret wishes death upon Ploni and his son for attempting to subvert Jews. See MQp 17, p. 56 / MQd 35, p. 398, 11. 45-52.

20. An allusion to the story of Samson and the lion, told in Judges 14; Samson's collection of the honey from the lion is a positive act, and functions here as an underhanded compliment: while Levi may manage to extract goodness from a dangerous situation, he is in peril doing so.

21. I have translated the last word in this sentence according to the textual variant parashta, "you left" as opposed to pirashta, "you interpreted," as Dimitrovsky prefers, since it seems to me a more sensible parallel to nikhnasta, "you entered"; but in either case, the import is that Levi has deviated from the way of the Torah. 


\title{
Tamar Ron Marvin
}

illuminate the eyes of many with Gemara and Mishnah. If you intended to erect a fence around the holy Torah with the words of the philosophizers, leave it be, since this approach is forced and idiosyncratic. ${ }^{22}$

In addressing Levi directly, Ibn Adret is noticeably mild. He implies that there may be instances where philosophy has something interesting to say about Scripture, but nevertheless presses Levi to leave aside his rationalist fascinations and return to teaching traditional subjects. Ibn Adret continues, writing to Levi as though to a peer:

\begin{abstract}
You and I both know that not everybody's intellect is equal; there are those who are weak of intellect and if you instruct them in this knowledge, it will only make the parched thirstier. What will it contribute or add to your life if you take upon yourself responsibility for their souls, since you do not have a way of knowing whether they will live due to this knowledge, or perish and be liable for punishment? Do you not know that such knowledge is dangerous to the Torah, and that the [proverbial] bedcover is too narrow to contain them both? ${ }^{23}$
\end{abstract}

It is here that Ibn Adret comes closest to defining Levi's transgression as he sees it. Again, the problem does not stem from what Levi himself believes: Levi is among those gifted with the intelligence to discern the truth within philosophy. However, those who read or hear what Levi teaches may be spiritually imperiled.

In the background of this discussion lurked the specter of Christian involvement in Jewish affairs due to activities like those in which Levi was involved, as had occurred during the Maimonidean controversy of the 1230s. ${ }^{24}$ Ibn Adret was almost certainly concerned about such external involvement. To this end, he argued that Christians would not tolerate behavior like Levi's in their own community: "If this was now made known to the gentiles, they [the opponents of the ban] would not be able to escape; gold and silver would not save them from their

22. MQd 16, p. 55 / MQd 34, p. 393, 11. 41-47. Ibn Adret is here citing the rabbinic interpretive principle de-hi' mukma' 'a-nafsheih, leaving aside a forced literal meaning in favor of a contextual reading, e.g. as used in B. Pesahim 59b.

23. MQd 16, p. 55 / MQd 34, p. 393, 11. 47-51. The last sentence in this selection is based on Isaiah 28:20, "The couch is too short for stretching out and the cover too narrow for curling up." The midrashic reading of this verse suggests that the latter clause refers to Manasseh bringing an idol into the temple, as recounted in 2 Chronicles 33:7 (as Rashi notes in contradistinction to his own reading); it seems that the midrashic sense is what Ibn Adret has in mind here, and that he is likening philosophy to idolatry - if only in a literary sense.

24. Certainly he could not have been untouched by knowledge of very real Christian machinations against heresy, including heresy within the ranks of Christianity, which rent Occitania in the 1220s and prompted the institution of a papal inquisition. Nor could he have forgotten the increasing charge against Jews of anti-Christian blasphemy, invoked by the mendicant movement and in popular antiJewish libels throughout the thirteenth century. But see Jacob b. Makhir's lack of concern over Christian involvement, and his praise for Christians' assimilation of Greek knowledge into their educational curriculum in his letter, MQp 39, p. 85 / MQd 58, p. 510, 11. 54-60. 
immorality." 25 Ibn Adret would repeat this in his first letter to the Montpellier kahal (intended for public circulation): "All the nations [goyim] would condemn them [students of philosophy] as transgressors [koferim] on grounds of even one of their claims." 26

Ibn Adret was sensitive to the fact that allegoresis was an important tool in Christian scriptural interpretation. Comparing Christian allegoresis to that of Jewish rationalists, Ibn Adret writes "The decree made by him [Levi] and his supporters is harsher than that of the gentiles: if the gentiles proffer and interpret two or three verses according to their opinion, he and his supporters don't leave a single letter of the Torah alone. Gentiles leave some gleanings of Torah, while he and his ilk libel it completely. Could there be a stranger and foreigner more alien and brutal among all the nations?"27 Ibn Adret's argument, if disingenuous in its intent to shock, nevertheless counts Levi's alleged allegorization as worse than Christians' selective typology and allegoresis. He soon extends this sentiment to Muslims as well, writing of Levi: "A man like this cuts down the shoots-shall a person like this enter the home of one of us Jews? ${ }^{28}$ God knows that it's preferable in my view to listen to a gentile [goy] or Ishmaelite than to learn from a man like him. ${ }^{, 29}$ While seeking to distance such interpretive methodology from the Jewish intellectual toolbox, Ibn Adret was careful in his criticism of Christian interpretive tradition, utilizing a clever paradox that presents Jewish allegoresis as more insidious than that of non-Jews.

Reflecting his concern about outside involvement, Ibn Adret also argued that allegoresis dangerously courted interfaith discussion. While it may be preferable to listen to a non-Jew than the likes of Levi, better still is to associate with neither. Responding to the contention that logic was a necessary weapon in combating Christian conversionary activity, Ibn Adret insists that rationalism is too dangerous a tool to be used for that purpose: "If you argue that his [Levi's]

25. MQp 14, p. 56 / MQd 32, p. 383, 11. 123-24.

26. MQp 20, p. 61 / MQd 38, p. 412, 1. 55. Some manuscripts have ve-ya'anishu 'otam 'al ha-goyim ha-kofrim rather than ve-ya'anishu'otam kol ha-goyim ke-kofrim, possibly indicating that the line is to be read, "They should be condemned above the heretic gentiles" (MS Mich. 596, Bodleian Library, Oxford [ $[$ in Dimitrovsky's apparatus] and MS héb. 970, Bibliothèque Nationale, Paris [ 7 in Dimitrovsky's apparatus] — as well as MQp). One manuscript has va-ya'anishu 'otam 'al ha-goyim ke-koferim, "They should be condemned as heretics more so than gentiles" (MS Gruenzburg 63, Russian State Library, Moscow [ג in Dimitrovsky's apparatus]).

27. MQp 14, p. 51 / MQd 32, p. 381, 11. 92-96. This letter is Ibn Adret's response to Crescas Vidal's report about Levi.

28. This seems to be a doubly significant reference to ha-Sulami's sheltering of Levi and to the allegorizers' synogogal sermons.

29. MQp 14, p. 51 / MQd 32, p. 381, 11. 102-4. This is an instance in which goy clearly refers to a Christian rather than a non-Jew generically, as it is juxtaposed to 'Ishmael, "Muslim." The expression "cutting down the shoots" refers to the transgression of Elisha b. Abuyah, occurring in the rabbinic story of the four who entered the orchard, recorded in the pericope extending from B. Hagigah $14 \mathrm{~b}$ through 15b, with parallels in Y. Hagigah 2:1 (77b), T. Hagigah 2:1-7, and in the hekhalot corpus. For a structural outline of the pardes story, see Jeffrey L. Rubenstein, Talmudic Stories: Narrative Art, Composition, and Culture (Baltimore, MD: The Johns Hopkins University Press, 1999), 232. 


\title{
Tamar Ron Marvin
}

intent is nothing other than refuting the gentile heretic [ha-'epikoros ha-nokhri] who speaks against our Torah, if it were permitted for him to learn from [the heretic], he will neither be for us nor for our adversary. ${ }^{30}$ As Ibn Adret presents it, the no-man's-land of Greek philosophy, with its disregard for the authority of Scripture, is worse than silence in response to Christian proselytism. He pledges to Crescas, "Those of us who have been awakened [to rationalist impropriety] have not yet given up on rescuing [Judaism] from the hands of those who are 'gentilized' [mitnakrim] even more than the gentiles [nokhrim]!"31

Having explained the danger inherent in allegoresis as an interpretive tool for reading Scripture, Ibn Adret suggests that it can lead to misunderstanding of the Torah's commandments:

\begin{abstract}
What will such a man do with the commandments of the Torah? Regarding that which the nations denounce, reason implies that the Torah does not mean what it means, for the gentile can [use reason to] interpret as he wishes, for good or ill. Even if wise men have already interpreted it [the Torah], these people will interpret the interpretations, though it is not good to listen to the gentiles who interpret a few of the commandments as parables, or to interpret as per the method of those who abhor justice. The holy people would be doing an injustice by accepting his [Levi's] book. ${ }^{32}$
\end{abstract}

Here, Ibn Adret has connected "reason" as a method of scriptural exegesis with improper understanding of biblical commandments, using the example of Christian parabolic readings. He does not explicitly connect such mistaken readings with nonobservance of Jewish law, as he, along with a group of Barcelona nikhbadim (gentlemen) would later do in promulgating the text of the Barcelona ban of excommunication:

They [philosophizers] say that from "In the beginning" to the giving of the Torah, everything is a parable - Abraham and Sarah are Matter and Form, the twelve sons of Jacob are the twelve signs of the zodiac, the four kings who fought the five [in Genesis 14:1-2] are the four elements and the five senses [respectively]. We've heard that they decided to reach beyond that to comment on the mitzvot, [claiming] that the Urim and Thummim are the instrument called the astrolabe; regarding tefillin and prayer, they made of them frivolity. Nor do they fear to speak against Moses, saying-God forbid [that it be so] — that he was a philosopher-king, ${ }^{33}$ by claiming that the Torah is not from heaven, but merely ideas and decisions that Moses

30. MQp 14, p. 51 / MQd 32, pp. 380-81, 11. 86-87. The antecedent is not entirely clear, but this occurs in the context of Ibn Adret's response to Crescas Vidal, in which Crescas suggests that perhaps Samuel ha-Sulami agreed to board Levi in order to better understand Levi's views and refute any heretical ones (in MQp 12, p. 47 / MQd 30, p. 368, 11. 50-51).

31. MQp 14, p. 52 / MQd 32, pp. 383-84, 11. 132-34.

32. MQp 14, p. 56 / MQd 32, pp. 382-83, 11. 115-20.

33. In context, this seems to be the meaning of nimus (as in Bereshit Rabbah 65:20 and B. Megillah 12b), as pointed out by Dimitrovsky (p. 734, n. to 1. 34). 
made. It got to the point that one of them said, preaching before many in the synagogue, that it is perplexing why Moses saw fit to prohibit pork. This could be a result of his [the preacher's] wicked nature, but the fact is that wise men have not seen in him such a bad character. ${ }^{34}$ Another of them said that the commandment about tefillin does not mean that they should actually be laid upon the head and arm, because the intention [of this commandment] is simply for a person to comprehend and remember God. ${ }^{35}$ In other words, these [places on the body] are allusions: those [tefillin] laid on the head allude to the mind and those laid on the arm allude to the heart, which are the instruments of comprehension and memory [respectively], hinting that a person should comprehend and remember, and nothing other than that. From this point they "signal with a finger," ${ }^{36}$ extending a finger and speaking evilly of all the Torah's commandments. They remove the yoke from themselves and have no part of their [the commandments'] literal meaning. ${ }^{37}$ Each man and woman should do what is right in their view. ${ }^{38}$

This statement does not pertain to Levi specifically, but hints more explicitly at the dangers Ibn Adret, Abba-Mari, and their supporters feared. The nonobservance inherent in allegoresis certainly seems to haunt Ibn Adret's initial response to Crescas's report about Levi:

They [who follow or enable philosophizers] will abandon their [holy] books on account of the books of the Greeks, and the fire will consume their corpses. ${ }^{39}$ If, God forbid, there is not one grandchild or great-grandchild left loyal to the Torah who will be zealous and pursue them, then it [the Torah] will be annihilated, since these people are transgressors [kofrim] according to all religions and their excommunication is carved on the stone tablets of all the nations' books. ${ }^{40}$

34. That is, this man harbored transgressive ideas because he was convinced of them intellectually, not because of a congenitally wicked nature. Possibly, this line is a reference to Levi b. Abraham b. Hayim, who was in fact defended by "wise men"; see chapter 5 .

35. Here and elsewhere, the proponents of the ban are concerned about the class of axiomatic laws known as hukkim, which includes, for example, the laying of tefillin and the avoidance of wearing sha'atnez. See, inter alia, MQp ch. 2, p. 6/ MQd 2, p. 232, 11. 21-27; MQp 81(a), p. 153 / MQd 101, pp. 734-37, 11. 28-42, 54-59, 68-69. The hukkim are an ancient categorization developed extensively in the medieval period, by rationalists in particular-Sa'adiah Gaon, Judah ha-Levi, Abraham Ibn Ezra, Maimonides.

36. This is one of the adulteress's seduction tactics, according to B. Sotah 9a. In other words, the author(s) are saying here that all these allegations against the rationalists are the tip of the proverbial iceberg.

37. While "literal" is a reductionist translation of peshat, it fits the meaning here: that such rationalists reject any implication of actual, performative obligation derived from Scripture.

38. MQp 81(a), p. 153 / MQd 101, pp. 734-35, 11. 28-42.

39. I.e., they will not merit to enter the world to come.

40. MQp 14, p. 56 / MQd 32, p. 383, 11. 120-23. 


\section{Tamar Ron Marvin}

However, nowhere does Ibn Adret suggest that halakhic strictures were actually being violated, not by Levi nor by his students.

\section{Levi's Encyclopedias: Typical Fare or Subversive Material?}

Levi's surviving writings provide primary sources for his ideas, even if it is uncertain whether they were read by Crescas Vidal, Ibn Adret, or their supporters. Two major works by Levi survive (in part), Bate ha-nefesh ve-ha-lahashim (Charms and amulets) ${ }^{41}$ and Livyat hen (Graceful garland), ${ }^{42}$ both guides for

41. Bate ha-nefesh, Levi's first work, is composed of ten treatises (ma'amarim) written in rhymed prose that cover a range of topics at the heart of the rationalist enterprise: ethics, logic, creation, psychology (i.e., the properties of the soul), prophecy, mysticism, mathematics, astronomy, physics and metaphysics, mathematics, astronomy, and astrology. Levi records that he completed Bate ha-nefesh in 1276, in Montpellier, in the colophon to MS héb. 978, Bibliothèque Nationale, Paris; see Warren Zev Harvey, "Levi Ben Abraham of Villefranche's Controversial Encyclopedia," in The Medieval Jewish Encyclopedias of Science and Philosophy, ed. Steven Harvey (Boston: Kluwer, 2000), 171. Parts of it have been printed in critical editions; Israel Davidson published various sections of the former. The text of Levi's introduction appears in Davidson's "L'introduction de Lévi ben Abraham a son Encyclopédie Poétique Baté Ha-Néfeš Weha-Lehašim," Revue des études juives 105 (1940): 80-94. The first section of Bate ha-nefesh, along with an anonymous commentary, appears in Davidson's "The First Book of Battei ha-Nefesh ve-ha-Lahashim," Studies of the Research Institute for Hebrew Poetry in Jerusalem 5 (1939): 2-42; and the seventh section of the work in his article "Levi ben Abraham ben Hayim: A Mathematician of the Thirteenth Century," Scripta Mathematica 4 (1936): 57-65. More recently, Howard Kreisel published an edition of treatise 5 of Bate ha-nefesh in Livyat Hen: The Work of Creation (Book Six, Part Three) (Hebrew) (Jerusalem: World Union of Jewish Studies, 2004). The work is monorhymed, all of its lines ending with the syllable -rim. Levi took the title for Bate ha-nefesh from Isaiah 3:20, a passage that describes the adornments of the daughters of Zion. However, Levi states that the title is to be understood according to the decontextualized meaning of the phrase, "stanzas on the soul and the divine secrets": "I called these stanzas bate ha-nefesh ve-ha-lahashim because their purpose is to discuss the true nature of souls [amitat ha-nefashim] and the secrets of the Creator [lahashei ha-bore'] and His holy names, and the mysteries of His prophets [raze neviav] whom He guides with intention" (Davidson, "L'Introduction," 89, 11. 140-42). As Davidson points out, lahashim is to be understood according to its rabbinic connotation in B. Hagigah 14a.

42. Levi's magnum opus, Livyat hen, on which he worked continually from at least 1295 , was a vast expansion of Bate ha-nefesh. Parts of the extant sections have been published in critical edition by Howard Kreisel, including the introduction, part 1 and part 3 of treatise 6 (from the "Boaz" section), both long and short recensions, as Livyat Hen: The Work of Creation (Book Six, Part Three) (Hebrew) (Jerusalem: World Union of Jewish Studies, 2004) and Livyat Hen: The Quality of Prophecy and the Secrets of the Torah (Book Six, Introduction and Part One) (Hebrew) (Be'er Sheva: Ben-Gurion University Press, 2007). The colophon found in Vatican MS ebr. 192, f. 147r, records that the work was completed in Arles in 5055 (1295); see Colette Sirat, "Les Différentes versions du Livyat Hen de Lévi b. Abraham," Revue des études juives 122 (1963): 167-68. The 1295 version is conventionally known as the "short version," while subsequent expansions are termed the "long version." However, the first version that we have must not have been the first version of Livyat hen, since Levi notes in its colophon that he has made substantial revisions to the work, and requests of those in possession of earlier versions to replace them with the revised edition (see W. Z. Harvey, "Controversial Encyclopedia," 173-74; and Gad Freudenthal, "Sur la partie astronomique du Livyat Hen de Lévi ben Abraham ben Hayim," Revue des études juives 148 [1989]: 106).

The work is divided into two sections, named for the twin bronze pillars in Solomon's temple, Yachin and Boaz (described in 1 Kings 7:15-22); "Yachin," itself subdivided into at least five treatises, 
curious initiates, along with two shorter works, an astrological treatise known as Sefer ha-tekhunah and a poem titled by Levi "Be-hitnazluti u-telunati 'al ha-zeman" (Complaint against fate). ${ }^{43}$ Bate ha-nefesh and Livyat hen are encyclopedic, after the fashion of textbooks intended for those curious about science and philosophy. Levi is explicit on the purpose of his encyclopedias: "It is the nature of man to desire a summary, and it is useful to him ... it should be in accessible language, understandable, clear, and brief ... and insomuch as his manner [of learning] is through verse and literary rhetoric, he [such a man] will not be disappointed ... I organized these weighty matters concisely and completely, for it is not my intention to merely provide poetry and parables, but to clarify truths according to my thinking." 44

Both encyclopedias were popular works. ${ }^{45}$ More precisely, certain sections of the massive Livyat hen won popularity while others did not, which is probably

deals with knowledge attained by reason ( $h a-m u s k a l$ ) while "Boaz," divided into at least seven treatises, explores knowledge attained through received tradition (ha-mekubal). Each of the treatises ( $a^{3} a$ marim) that make up the two central "pillars" ('ammudim) is itself subdivided into parts (halakim) and then again into chapters (perakim), although, as W. Z. Harvey points out, the Treatise on Astronomy (pillar 1, treatise 3 ) is further subdivided into subchapters (she arim, literally "gates" but here a calque of the Arabic term $b \bar{a} l$, as pointed out to me by Raymond Scheindlin) and paragraphs (simanim). This schema of pillar: treatise: part: chapter: subchapter reflects the magnitude of Levi's project and has often confused those who cite it. The treatises are numbered consecutively, with treatises 1 through 5 composing pillar 1 and treatises 6 and 7 composing pillar 2, which is known to be incomplete. See W. Z. Harvey's remarks and a helpful schematic of Livyat hen's known contents in "Controversial Encyclopedia," 174.

43. Levi's astrological treatise survives in a unique manuscript, Cambridge MS Add. 1563.3, ff. 92r-104v, in which it is attributed to "R' Levi bar Gershom ba'al bate ha-nefesh ve-ha-lahashim"; see Stefan C. Reif, ed., Hebrew Manuscripts at Cambridge University Library: A Description and Introduction (Cambridge: Cambridge University Press, 1997), 335-36 (SCR 597). It appears the scribe here mistakenly refers to Levi b. Abraham as Levi b. Gershom. Levi's poem, the incipit of which is "Ani me ir 'ele hakham," is often referred to as the "Complaint" due to the headnote, apparently composed by Levi, which appears in the manuscript as "be-hitnazluti ve-telunati 'al ha-zeman / ve-lehakkhish 'en kol hadash hayiti mezuman." This short poem of twenty-four lines is appended to Bate ha-nefesh and has been published by Davidson along with the first book of Bate ha-nefesh in "The First Book of Battei ha-Nefesh," 40-42.

44. Davidson, "L'Introduction," 86, 11. 76-80, 89, 11. 116-18. Levi stresses his initial reluctance and caution about popularizing rationalism. It is only due to a dream-vision that he was finally emboldened to undertake the work. Levi writes, "Finally the worries of my heart and my perplexity lulled me to sleep, and I saw, there, a man speaking to me ... he said to me, 'Man, awake and arise and be strengthened in your task, and do not fear; produce what your heart demands and that which your soul is capable of. Do so and you will accomplish [these demands]"' (Davidson, "L'Introduction," 87, 11. 83-85). Levi clearly felt that his first work was both too small and too opaque to serve his purpose of making philosophy available to the seeker. He began Livyat hen after finishing Bate ha-nefesh, as an expansion of the task begun in the latter (recorded in the colophon). The title, which references Levi's name in the medieval fashion, is lifted from Proverbs 1:9, 4:9 and appears to be a reference to wisdom, due to the association of the livyat hen with wisdom in Proverbs as well as in M. Avot 6:7.

45. They survive in fifteen and eighteen manuscript copies respectively. Bate ha-nefesh garnered several commentaries in the fourteenth century, one by Frat Maimon, the leader of a circle of philosophical study in postexpulsion Occitania: MS héb. 981, Bibliothèque Nationale, Paris, includes 


\section{Tamar Ron Marvin}

why large portions of the work are not extant while certain sections are extant in multiple manuscripts. This pattern indicates that Levi's work was appreciated most for its theological content and less so for its natural philosophy, save for the exposition of astronomy and astrology, which is well preserved. ${ }^{46}$ Whether owing to the copiousness of Levi's coverage of the latter or to the particularities of his writing, it seems he was more influential as an expositor of Jewish texts than of Greek ones. Even so, just a generation after the controversy, Isaac b. Judah de Lattes in his Sha'arei ziyon characterized Livyat hen as a woefully forgotten work, praising it for its erudition and usefulness. ${ }^{47}$

Was anything about Levi's consummately Occitan rationalist works particularly transgressive? Historians of ideas have characterized the content of Bate ha-nefesh and especially of Livyat hen as "conservative Maimonidean" in terms of theology and "radical" in terms of exegesis of biblical and rabbinic texts. ${ }^{48}$ Yitzhak Baer states of Livyat hen, "There is hardly anything in this book which can be construed as heretical. ${ }^{, 49}$ Levi is indeed careful to begin each section of allegorical interpretation in Livyat hen by insisting on the coexistence of allegorical and literal readings - although it may be, as Colette Sirat suggests, that his insistence is overshadowed by the fact that "these two or three lines of orthodox declaration are followed by several pages of allegory." ${ }^{\circ 50}$ It is true, and striking, that much of the specific allegoresis that proponents of the ban found objectionable is to be found in Levi's writing.

a commentary by one "Solomon" (mentioned on fol. 75v), who has been identified with Frat Maimon, whose Hebrew name was Solomon b. Menahem. Sections of this commentary have been published by Kreisel: on treatise 3 of Bate ha-nefesh, in Livyat Hen (2004), 425-34, and on treatise 5, in Livyat Hen (2007), 951-65. A long and short anonymous commentary is to be found, following each stanza, in MS Evr. I 463, Russian National Library, St. Petersburg; Vatican MS Urbinati ebr. 43, Vatican City; MSS héb. 978, 979, and 990, Bibliothèque Nationale, Paris; MS hebr. 200, Oesterreichische Nationalbibliothek, Vienna; and MS Mich. 63, Bodleian Library, Oxford. Kreisel published the long and short versions of the anonymous comments on treatise 3 of Bate ha-nefesh in Livyat Hen (2004), 425-34, 450-54; and on treatise 5 in Livyat Hen (2007), 911-46, 966-70. Several manuscripts also bear marginal comments, dating from as early as the fourteenth century, and MS Parm. 3589, Biblioteca Palatina, Parma, a fourteenth-century manuscript, includes extensive marginalia that incorporates parts of the anonymous commentary. This places the composition date of the anonymous commentary in the fourteenth century.

46. Kreisel, Livyat Hen: The Work of Creation, 4-5.

47. "Sha'arei ziyon," in Menahem ha-Me'iri, Sefer seder ha-kabbalah, rev. ed., ed. S. Z. Havlin (Jerusalem: Ofeq Institute, 1995), 178, cited in Kreisel, Livyat Hen: The Work of Creation, 3.

48. The terminology is W. Z. Harvey's in "Controversial Encyclopedia," 177; but see also Colette Sirat, A History of Jewish Philosophy in the Middle Ages (Cambridge: Cambridge University Press, Editions de la Maison des Sciences de l'Homme, 1985), 245-55 and Halkin, "Why Was Levi b. Hayim Hounded?," 74-75.

49. Baer, History of the Jews in Christian Spain, 1:292.

50. Sirat, History of Jewish Philosophy, 245-46. See also Dov Schwartz's assessment, in which he calls some of Levi's allegories "quite radical": "Greek Wisdom': A Reexamination in the Period of the Controversy over the Study of Philosophy," Sinai 104 (1989): 148. 
Throughout the Minhat kena'ot letters, among them those cited above, ban proponents routinely levy several distinct allegations about their opponents' views, citing them as propagandistic slogans. These include the figuration of Abraham and Sarah as Form and Matter, the Urim and Thummim as the astrolabe, the twelve tribes as the twelve signs of the zodiac, and the four kings of Genesis 14:1-2 an allegory for the four elements. ${ }^{51}$ These were "defective allegories," as Ibn Adret complained in his letter to Levi about those who "had distanced themselves from their fellows, filling whole rooms with the books of Aristotle and Plato, interpreting by means of defective allegories [dorshim be-haggadot shel $d o f i] . "{ }^{\circ 2}$ By far the most frequently invoked slogan is that Abraham and Sarah were figurative constructions representing Platonic-Aristotelian Form and Matter, ${ }^{53}$ rather than actual human beings. As a counterpoint, Ibn Adret went as far as to define a proper believer as "a believer in Abraham and Sarah and their son Isaac"- that is, as one who objected to the allegorizing the patriarchs and matriarchs. ${ }^{54}$

The allegories about Sarah and Abraham, the twelve tribes, and the four kings are all found in Levi b. Abraham's Livyat hen. ${ }^{55}$ However, they are hardly representative of Levi's central concerns, nor of the density of his

51. Though these slogans reflected ideas found in rationalist literature, their uniformity and the number of times each is repeated indicates that they were reductionist. In addition to these refrains caricaturing the ideas of their opponents, ban proponents also charged their opponents directly with denying four distinct theological positions: the existence of miracles, prophecy, divine providence, and the world's createdness. In his headnote to the first public circulatory letter sent between Barcelona and Montpellier, for example, Abba-Mari explains that this letter was intended to advise rationalists on how to deal with the "two or three" radicals in their midst, "who deny [koferim] the miracles of the Torah [mofte ha-Torah], do not believe in providence [bilti ma'aminim ba-hashgahah], and interpret the principles of the Torah ['ikarei ha-Torah] as trite" (MQd 38, p. 409, 11. 6-7). Abba-Mari once described Ibn Adret thus: "He [Ibn Adret] wages war with Aristotle and his allies who believe in the eternality of the universe [ha-kadmut], deniers of the miracles [makhishei ha-moftim] who diminish the divine, deniers of providence [koferim ba-hashgahah] who do not give ear" (MQd 23, p. 65 / MQd 42, p. 427, 11. 16-18). Later, in writing the theological introduction to Minhat kena'ot, Abba-Mari would propose a creed of three principles that emphasized God's supremacy, the creation of the world, and divine providence. (See especially MQp ch. 4, p. 7 / MQp 4, pp. 235-36, as well as MQp chs. 5, 10, 13, and $15 / \mathrm{MQd}$ chs. 5, 13, and 15. The only one of these principles elaborated upon in Sefer ha-yareah is divine providence, but within the context of discrediting Aristotle, not as a creedal principle in and of itself; see ch. 7 of Sefer ha-yareah MQp, p. 127 / MQd 77, p. 654.)

52. MQp 16, p. 54 / MQd 34, p. 392, 11. 27-28. In another letter, he complained of careless rationalists, "They falsified the Torah and its commandments [samu ha-Torah u-mizvoteiha plaster], so that it became for them a sanctioned release from obligation [heter]" (MQp 10, p. 45 / MQd 28, p. 360, 11. $18-19)$.

53. The order is always given as "matter and form," for the sake of the Hebrew rhymeAvraham ve-Sarah / homer ve-zurah - although Abraham was identified with form (zurah) and Sarah with matter (homer). See Ram Ben-Shalom, "Communication and Propaganda between Provence and Spain: The Controversy over Extreme Allegorization (1303-1306)," in Communication in the Jewish Diaspora: The Pre-Modern World, ed. Sophia Menache (Leiden: Brill, 1996), 181-82.

54. MQp 49, p. 105 / MQd 68, p. 578. 1. 28.

55. Charles Touati, "La controverse de 1303-1306 autour des études philosophiques et scientifiques," Revue des études juives 117 (1968): 30-31. These appear in treatise 6; Touati cites the "short 


\section{Tamar Ron Marvin}

exposition. For instance, the suggestion that Jacob's sons are to be conflated with the zodiac occurs within the context of a broader discussion about Jacob's ascendency over Esau. Levi argues that Jacob's encounters with angels may be understood astrologically, in that the embodied angels who visit him are governed by the stars, which constitute a class of angels - an argument built upon Abraham Ibn Ezra's comment on Genesis 23:20. "It is possible that the star ruling over the constellation at that time was responsible for Jacob's success," Levi writes. ${ }^{57}$ Though there is much that a traditionalist might find objectionable here, Levi notably does not argue that Jacob is solely a symbol and not a historical personhe supplements without supplanting the peshat.

In addition to the fact that the most emblematic rationalizing allegories are found in Levi's written works, his style and scope may have raised concerns as well. ${ }^{58}$ Livyat hen is written in remarkably accessible Hebrew and succeeds in its mission of covering the medieval philosophical omnibus for the uninitiated scholar; while clear, it is not simplistic, making this an often sophisticated text. Levi does not shy away from controversial topics, though he covers them matter-of-factly. Philosophical ideas of non-Jewish origin clearly inform, even permeate, Levi's understanding of Scripture. For example, in Levi's discussion of the immutable nature of the Torah, he echoes Maimonides in describing the Torah's "intention that we walk the straight path, the middle course," adding, "And thus Aristotle elucidated in the Ethics, that the middle course is the correct way in all behavior." 59

While Levi was certainly exemplary of the type of popularizer of philosophy Abba-Mari and Ibn Adret excoriate in their campaign, the fact remains that the controversial ideas presented in Levi's works are neither unique to his writings nor more popular than those of a number of contemporaries. Livyat hen competed with at least three contemporary philosophical encyclopedias in Hebrew, Midrash ha-hokhmah by Judah b. Solomon ha-Kohen Ibn Matkah (fl. first half of the thirteenth century), Sha'ar ha-shamayim by Gershom b. Solomon of Arles (fl. late thirteenth century), and Dé ot ha-filosofim by Shem-Tov Ibn Falaquera (1223/8-

version" of Livyat hen preserved in MS Mich. 519, Bodleian Library, Oxford, in which these allegories occur on ff. $38 \mathrm{v}, 68 \mathrm{v}$, and $71 \mathrm{v}$, respectively.

56. In the long version of Livyat hen, treatise 6, part 1, chapter 32 (in pillar 2, "Boaz"); published in Livyat Hen: The Quality of Prophecy and the Secrets of the Torah (Book Six, Introduction and Part One) (Hebrew), ed. Howard Kreisel (Be'er Sheva: Ben-Gurion University Press, 2007), 703-4.

57. Kreisel, ed., Livyat Hen: The Quality of Prophecy, 704.

58. Kreisel, ed., Livyat Hen: The Work of Creation, 5, n. 15.

59. Kreisel, ed., Livyat Hen: The Quality of Prophecy, 305. Cf. Shemonah perakim 4 and Moreh II, 39. In addition to these characteristics, Levi's magnum opus displays originality at times. Consider a passage in which Levi addresses the use of figurative language in Hebrew, in which he adds the term harhavah, similar but distinct from guzma' (hyperbole) (Livyat Hen: The Quality of Prophecy, 103). This rare term, which Levi may have used following an unattributed text, seems to be an unusual, perhaps original suggestion. 


\section{A Heretic from a Good Family?}

after 1290), all popular works. ${ }^{60}$ In fact, all three works were far more successful as popular guides to philosophy. ${ }^{61}$

When opponents of the ban protested in Montpellier, it was Jacob Anatoli's Malmad ha-talmidim that they selected to read aloud in defiance of traditionalist sensitivities. ${ }^{62}$ Based on the evidence of his extant writings, it seems that the

60. There are other examples of "textbooks" from the period. Midrash ha-hokhmah (Exposition of wisdom), an encyclopedia by Judah b. Solomon ha-Kohen Ibn Malkah of Toledo (b. c. 1215), was originally written in Arabic but translated by Judah himself into Hebrew while at the court of Frederick II in Lombardy. Like Levi's encyclopedias, Midrash ha-hokhmah encompasses natural philosophy, mathematics and astronomy, and metaphysics (which constitute each of its three parts). It was quite popular, judging from the twenty extant manuscripts (Sirat, History of Jewish Philosophy, 250-55). Gershom b. Solomon of Arles (fl. second half of the thirteenth century), wrote a similar tripartite encyclopedia, Sha'ar ha-shamayim (Gateway to the heavens), which Steven Harvey has called "the most popular thirteenth-century encyclopaedia" (see his "Shem-Tov Falaquera, A Paragon of an Epigone," in Studia Rosenthaliana 40 [2007-8]: 61-74). Perhaps best known today are the popularizing works of Shem-Tov Ibn Falaquera. His major work is the encyclopedia Déot ha-filosofim, which has never been published in its entirety from the two extant manuscripts. Ibn Falaquera produced two more "little encyclopedias," as Sirat terms them (History of Jewish Philosophy, 234): Reshit hokhmah (The beginning of wisdom) and Sefer ha-mevakesh (The book of the seeker). Both works are extant in a large number of manuscripts-Reshit hokhmah in seven, as well as one Latin translation, and Sefer ha-mevakesh in nine - attesting to their popularity. Ibn Falaquera's 'Iggeret ha-vikuah (Epistle of debate) is also a guidebook for young students interested in philosophy; it too is well preserved (extant in seventeen manuscript copies). In addition, one of Yedayah ha-Penini Bedersi's youthful works - written at the age of seventeen, he states - was an ethical work in encyclopedic format, titled Sefer ha-pardes (Book of the orchard), published by J. Luzzato in 'Ozar ha-sifrut 3, no. 6 (1889/90): 1-17. This makes the composition date of Sefer ha-pardes almost exactly contemporaneous to that of Levi's Bate ha-nefesh.

61. In addition to encyclopedic works, another genre that had become popular in the region in Levi's time, aggadic and midrashic commentary, sought to explain these core texts of Jewish tradition in nonliteral terms. Among these works is Ibn Adret's own Perushe ha-haggadot (extensively cited in Jacob Ibn Habib's later aggadic compilation and commentary, the 'Ein Ya'akov); Moses Ibn Tibbon's Sefer ha-pe'ah; Yedayah ha-Penini Bedersi's Perush ha-midrashim; Shemaryah b. Elijah ha-'Iqriti's 'Elef ha-magen, a commentary on the aggadot of tractate Megillah; and Isaac b. Yedayah's commentaries on talmudic aggadah and on Midrash Rabbah, in which he often notes the distinction between his own rationalistic explanations and those of the sages. Such commentaries were part of the Maimonidean project of explaining the Torah's secrets, as well as, significantly, a counterpolemical response to contemporary Christian missionizing strategies. Further comparison of methodologies between these aggadic-midrashic commentaries and philosophical-allegorical biblical interpretation in thirteenth- to fourteenth-century Iberia and Occitania is a desideratum. See Marc Saperstein, Decoding the Rabbis: A Thirteenth-Century Commentary on the Aggadah (Cambridge, MA: Harvard University Press, 1980); Saperstein, "R. Isaac B. Yeda'yah: A Forgotten Commentary on the Aggadah," Revue des études juives 138 (1979): 17-45, and "Yedaiah Bedersi's Commentary on the Midrashim," World Congress of Jewish Studies 8, no. 3 (1982): 59-65; Carmi Horowitz, “Al perush ha-'aggadot shel Rashba: Bein kabbalah le-filosofiah," Da'at 18 (1987): 15-25; Marjorie Lehman, The En Yaaqov: Jacob Ibn Habib's Search for Faith in the Talmudic Corpus (Detroit: Wayne State University Press, 2011); Haim Kreisel, Colette Sirat, and Avraham Israel, eds., Kitvei Rabbi Moshe Ibn Tibbon (Be'er Sheva: Ben-Gurion University Press, 2010); Barry Walfish, Esther in Medieval Garb: Jewish Interpretation of the Book of Esther in the Middle Ages (Albany: State University of New York Press, 1993), 33-34; Robert Chazan, Daggers of Faith: Thirteenth-Century Christian Missionizing and the Jewish Response (Berkeley: University of California Press, 1989), 86-88. 


\section{Tamar Ron Marvin}

reason that Levi was targeted specifically, among others, came down to a matter of perception: his detractors' sense that he was insufficiently pious, too cavalier in interpreting Scripture and aggadah, overly enamored with the powers of the mind.

\section{A Heretic from a Good Family}

It has been widely suggested, following Halkin, that Levi was singled out in large part because of his presumed lower socioeconomic status. This is Halkin's conclusion, in which he follows Leo Baeck's earlier assessment. ${ }^{63}$ There is certainly evidence that Levi encountered financial adversity. For one, there is the simple fact that as an elderly man he had to work, or rely on the charity of family members, in order to have a place to live. More directly, in his report cited above, Crescas Vidal noted that Levi taught philosophy indiscriminately "because he had fallen on hard times." 64 As a generality, teachers of the young (melamdim, a term usually reserved for teachers of children) had a low social standing in medieval Jewish society and were poorly compensated for their work. $^{65}$ There is perhaps an echo of the reduction in social status Levi suffered in his remark in his "Telunati 'al ha-zeman," "They considered me a foreigner on account of my knowledge; they betrayed me and plotted against me."66 Indeed, Levi was apparently compelled to move frequently due to job insecurity: his statements in the introductions and colophons of his works place him at Montpellier in $1276,{ }^{67}$ in Arles in $1295,{ }^{68}$ and in Perpignan and then Montpellier in $1304 .^{69}$

62. The public reading occurred in Montpellier after Minhah on Shabbat Parah (following Purim). Shelemyah de Lunel, who helped to spearhead the event and his supporters pledged to do so every following Shabbat as well: MQp 68, p. 139 / MQd 87, p. 692, 11. 39-42.

63. Halkin, "Why Was Levi ben Hayyim Hounded?," 68-70; Leo Bäck, "Zur Charaktersitik des Levi ben Abraham ben Chajjim," Monatsschrift für Geschichte und Wissenschaft des Judentums 44 (1900): 28-30; and see also Touati, "La Controverse de 1303-1306." See also Sirat, who suggests that Levi was an ideal scapegoat for yet more illustrious men, including Maimonides and the Tibbonides, precisely because he represents the end of an intellectual epoch, having taken the methodology of the post-Maimonideans to its logical conclusion. This is Sirat's response to the consensus view that Levi was targeted due to his personal poverty (see below), of which she writes, "There is certainly some truth to this hypothesis" (History of Jewish Philosophy, 246).

64. MQp 12, p. 48 / MQd 30, pp. 369-70, 1. 69.

65. See Ephraim Kanarfogel, Jewish Education and Society in the High Middle Ages (Detroit: Wayne State University Press, 1992), 25-31; however, most of Kanarfogel's sources pertain to northern Europe specifically, and many to the twelfth and thirteenth centuries.

66. Davidson, "Introduction to Battei ha-Nefesh," 40, 1. 237. It is difficult to know how seriously to take Levi's complaint, however, considering the well-worn literary genre of complaint poetry.

67. According to the colophon of Bate ha-nefesh in MS héb. 978, Bibliothèque Nationale, Paris; see W. Z. Harvey, "Controversial Encyclopedia," 171.

68. The colophon to one of the long versions of Livyat hen records, "This copy was completed in the city of Arles at the end of the year 5055" (Vatican MS ebr. 192, fol. 147r). Another long version bears the date 1299, though without a location (Vatican MS ebr. 383, fol. 103v).

69. It is in the latter half of 1304 that Crescas Vidal first reports about Levi's whereabouts there (MQp 12, pp. 46-48 / MQd 30, pp. 365-72), and several other letters, all dating from 1304, mention him. The year 1304, then, is the last date attested for Levi. Though it has often been asserted that Levi is 
Again, however, Levi was hardly unique among pedigreed intellectuals in finding himself an itinerant teacher and textbook author. Rather than an indication of his negative reputation, this itinerancy seems the common lot of teachers and sermonizers, the most prominent example being Abraham Ibn Ezra. Even after Levi was compelled to leave his lodging in Perpignan, he quickly found another - in Montpellier, the seat of the Occitan ban campaign. More to the point, even with his financial difficulties, Levi remained a meyuhad (elite), garnering the aid and protection of leading community members as well as his prominent relatives. In fact, the allegations against him reflect his social standing and level of education: Levi was charged with being an agent of the spread of dangerous ideas. For all his fulminations, Ibn Adret ultimately has little leverage over Levi, as a fellow nikhbad and, more significantly, as a member of a community beyond Ibn Adret's jurisdiction. ${ }^{70}$ Ibn Adret asks him to curtail his activities by invoking the good name of Levi's family:

\begin{abstract}
Decide internally to do as your friends advise you; what you are doing is unbefitting for you and what they say suits you. Please do not take my advice lightly. Go out now and inquire of those who travel between there and here what they hear from those who are talking, and not quietly; after that you'll understand that people are coming to hear your words in order to criticize them, and are gossiping about you, be it truth or lies. Remove this obstacle from before you and your family willingly, and let your deeds and learning be your testaments. Why grasp at that which overturns your nobility? ${ }^{71}$
\end{abstract}

Indeed, Levi was clearly the scion of a prominent, well-established aristocratic family. This is a fact that bears emphasizing, considering that scholarship has tended to treat him like an outsider and easy scapegoat. There is some dispute about the date of Levi's death, but all evidence indicates that he was not only Abba-Mari's senior, but also well established as a scholar and teacher at the time Abba-Mari instigated the controversy. ${ }^{72}$ Information relayed in Minhat kena'ot, as well as in other extant sources, reveals Levi to be a member in good standing of the Occitan community. Based on prosopographical evidence, it

attested at Arles in 1315, I was unable to find a source for this. W. Z. Harvey thinks it is a misreading of the colophon found in Vatican MS ebr. 192; see "Controversial Encyclopedia," 171, n. 1.

70. The political separation between Barcelona and Montpellier was at a sensitive point at this juncture, and heightened the already extant boundaries among Jewish communal authorities. See Marc Saperstein, "The Conflict over the Rashba's Herem on Philosophical Study: A Political Perspective," Jewish History 1, no. 2 (1986): 27-38.

71. MQd 16, p. 55 / MQd 34, pp. 394-95, 11. 66-71.

72. W. Z. Harvey suggests that in 1276, when he completed his first encyclopedia, Levi was over forty, since he wrote explicitly that one should not delve into ma'aseh bere'shit and ma'aseh merkavah until attaining that age, following Maimonides and rabbinic precepts: see his "Controversial Encyclopedia," 181. If Harvey is correct, this would make Levi at least sixty-eight in 1304. In any case it is probable that Levi was elderly at the time of the controversy. 


\section{Tamar Ron Marvin}

appears that Levi's family originated in the old Occitan cultural corridor of Narbonne-Béziers-Lunel.

Levi's father, Abraham b. Hayim de Béziers, was a payetan; four of his kerovot were included in the eastern Provençal (Carpentras) rite in the Amidah of Shabbat Parah. ${ }^{73}$ Abraham is also mentioned by Menahem ha-Meiri in the preface to Bet ha-behirah, where he is referred to as a renowned scholar. ${ }^{74}$ Abraham was active in Narbonne in the first half of the thirteenth century and moved his family to Villefranche de Conflent before Levi was born. ${ }^{75}$ It is known from Levi's own writing that he was born in that town in the Roussillon, about fifty kilometers west of Perpignan, around the middle of the thirteenth century. ${ }^{76}$ Hayim, Abraham's father and Levi's grandfather, was also a prominent scholar, ${ }^{77}$ but perhaps the most renowned relative of Levi's was his uncle Reuben b. Hayim (d. before 1276), a talmudist and payetan in Narbonne. ${ }^{78}$ Reuben was a teacher of ha-Me'iri, who was a great admirer of his; ${ }^{79}$ another of Reuben's pupils

73. Two of the four kerovot include acrostics: one bears the acrostic "Abraham bar Hayim" and another “Abraham." See Leopold Zunz, Die Literaturgeschichte der Synagogalen Poesie (Berlin: L. Gerschel, 1865), 418; Ernest Renan, "Les Rabbins français du commencement du XIVe Siècle," in Histoire Littéraire de la France, 27:430-734 (Paris, 1877), 629; and Gross, Gallia Judaica, 421. Shabbat Parah is one of the four additional Torah portions ('arba'ah parshiyot) read during Shabbat services in the month preceding Passover. These include Shabbat Shekalim, Shabbat Zakhor, and Shabbat ha-Hodesh in addition to Shabbat Parah, and are thematically preparatory for the holiday. Shabbat Parah occurs on the Shabbat following Purim.

74. See Bet ha-behirah le-Rabbenu Menahem ben Rav Shelomo le-vet Me'ir ha-mekuneh ha-Meiri, ed. Shmuel Dikman, 20 vols. (Jerusalem: Makhon ha-Talmud ha-Isra'eli ha-Shalem, 1964). The general preface is not to be confused with ha-Me'iri's preface to his commentary on Avot, a celebrated part of Bet ha-behirah on account of its shalshelet ha-kabbalah that is known as Magen 'avot.

75. This is assumed based on the fact that Abraham is mentioned by others as being active in Narbonne, but that Levi states that he was born in Conflent.

76. Ernest Renan gives the probable date of Levi's birth as $1245-50$, though he derives this from two questionable sources: Levi's statement that he is young in a work of unknown date, and a description of Levi as elderly in Minhat kena'ot, which I have not been able to find in the place Renan indicates, MQp 12, pp. 46-47 (this is Crescas Vidal's first letter to Barcelona, quoted at length below); see "Les Rabbins français du commencement du XIVe Siècle," 630-31. Renan's date is the most frequently cited in subsequent scholarship. In contrast, W. Z. Harvey argues, based on evidence that Levi observed the prohibition on studying metaphysics before age forty, that Levi was born earlier, c. 1235: see "Controversial Encyclopedia," 181. If Harvey is correct, Levi would be precisely the same age as Jacob b. Makhir and Ibn Adret. I am unconvinced that a definitive date of birth can be determined for Levi.

77. For this reason, Levi is often cited as Levi b. Abraham b. Hayim or even Levi b. Hayim; at times an even longer pedigree is provided for him. There is some confusion over Levi's grandfather's name, which is either Hayim b. Reuben or Hayim b. Abraham. Two Oxford manuscripts (MSS Mich. 602 and Mich. 63) have Levi b. Abraham b. Hayim b. Reuben and two Paris manuscripts (MSS héb. 978 and 979, Bibliothèque Nationale) have Levi b. Abraham b. Hayim b. Abraham b. Reuben.

78. While Levi does not state that Reuben is his uncle, this is presumed from his relationship with Samuel b. Reuben de Béziers. It is also supported by patronymics: Abraham b. Hayim (Levi's father), Reuben b. Hayim, Samuel b. Reuben.

79. Also in the preface to Bet ha-behirah. 
was Manoah b. Simon of Narbonne (fl. c. 1280-1350), whose commentary on Mishneh Torah and other works were much cited. ${ }^{80}$ Reuben was himself the student of the Occitan great Isaac ha-Kohen (fl. thirteenth century), a disciple of Abraham b. David of Posquières and an associate of Ibn Adret. Samuel, Reuben's son (and Levi's first cousin), would write to Ibn Adret, "I know of my elderly father's admiring love for you, and the love of Solomon [Ibn Adret] the rabbi [for him], like the love for a son of one's old age." 81 In addition, Reuben was the author of two noted works: Sefer ha-tamid, a liturgical commentary cited by Aaron b. Jacob ha-Kohen of Lunel in his 'Orhot hayim, and, probably, a lost philosophical commentary on the aggadic passages of the Talmud. ${ }^{82}$ Samuel (Reuben's son and Levi's cousin) was to become Levi's benefactor, taking him in when the Perpignan nikhbad Samuel ha-Sulami turned him out. ${ }^{83}$ Samuel b. Reuben describes Levi, in a letter to Ibn Adret, as "A member of my family, of the dynasty of my ancestors, flesh of their flesh and bone of their bones"-he seems to be underscoring the excellence of Levi's family background, as well as the relationship between the cousins. ${ }^{84}$ Apart from these contemporaries, Levi likely had illustrious ancestors going back to the twelfth century. ${ }^{85}$ These

80. Manoah's Mishneh Torah commentary is known as Sefer ha-menuhah or Sefer ha-manoah and was cited by Isaac b. Jacob Lattes (fl. mid-fourteenth century) in Sha'arei Ziyon, the first part of his presentation of the oral law, Kiryat sefer; and, later by Joseph Karo in Bet Yosef and also in Kesef mishneh, Karo's commentary on the Mishneh Torah.

81. MQp 41, p. 90 / MQd 60, p. 526, 11. 26-27; cf. Dimitrovsky's reading of this phrase, p. 526, n. 27. Ibn Adret continued to maintain a close connection with the family even after Levi became the target of accusations of heresy - and after seeing Samuel b. Reuben's signature in support of the Montpellier rationalists: see MQp 42, p. 93 / MQd 61, p. 538, 11. 15-16.

82. This commentary, which is not extant, is attributed by Azaryah de Rossi to a Reuben b. Hayim; see Me’or 'enayim, ed. David Cassel (Vilna, 1864-66; rprt., Jerusalem: Makor, 1970), 127. This is pointed out by Ernest Renan in "Les rabbins français du commencement du XIVe siècle," 631-32.

83. In Livyat hen Levi calls his cousin Reuben b. Samuel de Béziers 'adoni, which Halkin reads as "father-in-law"; if Halkin's reading is correct, then Levi was married to his second cousin, the famed Reuben b. Hayim's granddaughter.

84. MQp 41, p. 91 / MQd 60. p. 532, 11. 100-101.

85. It is uncertain, but the relative rarity of the names Levi, Reuben, and Hayim may indicate that Levi was related to several prominent Occitans. The two most promising candidate is Abraham $b$. Hayim (fl. twelfth century), to whom Abraham Ibn Ezra dedicated his Sefer ha-Shem (along with Abraham b. Meir of Beziérs and Isaac b. Judah): see Sepher Haschem: Oder das Buch über den vierbuchstabigen Namen Gottes, ed. Gabriel Hirsch Lippman (Fürth: D. I. Zürndorff, 1834), Heb. sec. 1 א. Other possible relatives include the important early Occitan figure Moses ha-Darshan (fl. first half of the eleventh century), who had a brother named Levi; Jacob b. Reuben (c. 1136 - c. after 1170), author of an anti-Christian polemic titled Milhamot 'Adonai; and Levi b. Moses b. Todros (d. c. 1220) and the son of a Narbonne nasi' who was praised by Judah al-Harizi in the Tahkemoni for his philanthropic activities. David b. Levi (fl. late thirteenth - early fourteenth century), author of the important halakhic work Ha-mikhtam and a signatory of some of Ibn Adret's halakhic decisions, was probably not a relation, as he was a contemporary of Levi's, though he moved in the same elite circles in central Occitania as did Levi's confirmed family members. 


\section{Tamar Ron Marvin}

well-established and respected relatives gave Levi a sound reputation; ${ }^{86}$ their works also demonstrate that Levi's family produced philosophically oriented works while continuing to write in traditional genres, as was the custom of the Occitan elite classes. In view of Levi's demonstrable social prestige, it seems unlikely that he was targeted primarily due to his financial troubles.

\section{AN INADVERTENT TARgET}

It seems that Levi was targeted - rather than other popularizers of philosophy-inadvertently. That Levi was named at all as a suspected transgressor was the result of a misunderstanding on the part of Crescas Vidal. Crescas thought that Ibn Adret was looking for an exemplar for his ban of excommunication, and as such, he identified Levi as aptly fitting the bill. However, Levi was not targeted because of especially flagrant or radical activities.

The unfolding of this situation is clear from the surviving letters, cited above. Soon after Abba-Mari contacted Ibn Adret with his concerns about rationalist philosophy, the initially skeptical Ibn Adret turned activist. He quickly began to investigate whether Abba-Mari's claims had any truth, pressing his associates for information about transgressive behavior in Occitania. His first move was to contact a reliable colleague in Perpignan-Crescas - requesting a report

86. Though it has not been addressed by subsequent scholarship, Joseph Jacobs and Max Schlessinger conjectured in their article about Levi b. Abraham b. Hayim in the 1906 Jewish Encyclopedia (ed. Isidore Singer et al. [New York: Funk and Wagnalls, 1901-6], 8:22-24) that Levi was the maternal grandfather of Levi b. Gershom (Ralbag; Gersonides); and by Israel Davidson in his 1939 edition of the first book of Bate ha-nefesh, which includes a family tree in the introduction ("The First Book of Bate ha-nefesh ve-ha-lahashim" [Hebrew], Studies of the Research Institute for Hebrew Poetry in Jerusalem 5 [1939]: 3-4). Few details about Gersonides's life are known definitively, and the identity of both of his parents is disputed. For our purposes, it is unimportant whether his father was Gershom b. Solomon of Arles, author of Sha'ar ha-shamayim, as recorded by Abraham Zacuto in Sefer yuhasin (see H. Filipowski, ed., Liber Juchasin [London: Hevrat me'orere yeshenim, 1857], 224a) and repeated by Gedalya Ibn Yahya in his Shalshelet ha-kabbalah (see Shalshelet ha-kabbalah [Venice, 1587], 61a)—or whether his father was the talmudist Gershom b. Solomon de Béziers, as contended by Charles Touati and Seymour Feldman, inter alia, on the basis of details reported by Isaac b. Jacob Lattes in Kiryat sefer: see Charles Touati, La pensée philosophique et théologique de Gersonide (Paris: Les Éditions de minuit, 1973) and Seymour Feldman, ed., The Wars of the Lord by Levi Ben Gershom, 3 vols. (Philadelphia: Jewish Publication Society, 1984-99), 3:4-5. Either way, if Levi b. Abraham's daughter was indeed Gersonides's mother, she would have married into a prominent family - although considering Levi's age, this marriage would have taken place before the controversy and would thus not reflect his continued good standing in the community.

However, the identity of Gersonides's mother is even more problematic and is the determinant of whether he was related to our Levi. According to Zacuto (and others who followed him), Nahmanides, not Levi, was Gersonides's maternal grandfather, but this is contradicted by a remark Gersonides himself makes: he quotes his maternal grandfather as Levi ha-Kohen in his comment on Exodus 34:9 (Mantua, 1480, 114a). Since Gersonides himself is not known to be a kohen, this Levi ha-Kohen would have had to be his maternal, rather than paternal, grandfather - thus precluding Nahmanides from being Gersonides's maternal grandfather. Of course, Levi b. Abraham was not known to be a kohen either, so it would seem, in the final analysis, that our Levi b. Abraham was not the grandfather of the preeminent and controversial Jewish philosopher of the fourteenth century. 
on the activities of the philosophically minded there. It is easy to see why Ibn Adret chose him to be his source in Perpignan. Crescas was a recent transplant to Perpignan, whose self-perception was generally Occitan despite being located approximately halfway between Barcelona and Montpellier. ${ }^{87}$ Yet Crescas was originally a Barcelonan, a member of the distinguished Vidal family who had studied under Aaron b. Joseph ha-Levi (Rah, c. 1235 - c. 1300), Aaron being a colleague of Ibn Adret since their days as pupils of Nahmanides. ${ }^{88}$ As such, Crescas was a man of undeniable loyalty ideally placed to report on the situation in Occitania from the perspective of a Catalan. Furthermore, Crescas's brother Bonafos Vidal was living in Barcelona, at Ibn Adret's disposal. Bonafos wrote to Crescas in concert with Ibn Adret, encouraging his brother to become Ibn Adret's operative in Perpignan. ${ }^{89}$

Crescas replied, as discussed above, identifying Levi b. Abraham as just the type of radical rationalist teacher and popularizer that Ibn Adret asked him about. This revelation galvanized the effort to propose a ban guarding against the improper use of philosophy. Ibn Adret sprang into action, writing withering attacks on Levi and those like him, mostly to his own supporters. Samuel ha-Sulami was caught by surprise when it turned out that the learned, elderly man from a respected Occitan family, whom he had willingly taken into his home, was accused by Ibn Adret of being a possible transgressor. Even faced with Ibn Adret's vitriol, ha-Sulami sedately assured Ibn Adret of Levi's uprightness. ${ }^{90}$ The lack of deference and fear on the part of ha-Sulami in his initial response to Ibn Adret, as well as Crescas's own equivocal report, demonstrates that Levi was not considered particularly radical before Crescas pointed the finger at him, somewhat unwittingly. ${ }^{11}$ Soon thereafter, however, ha-Sulami's daughter became ill and died in the fall of $1304 .^{92}$ Ha-Sulami reportedly interpreted the sad event as divine judgment for hosting Levi, and he turned Levi

87. Emery, Jews of Perpignan, 1-10.

88. Baer, History of the Jews in Christian Spain, 1:292, 442 (n. 45). Baer suggests that the father of Crescas and his brother Bonafos was Vidal Solomon, bailiff to James I of Aragon. As he notes, Crescas Vidal is mentioned in Jean Régné, History of the Jews in Aragon: Regesta and Documents, 1213-1327, ed. Yom Tov Assis (Jerusalem: Magnes, 1978), nos. 2344, 2416, and, along with his brother, no. 1932; Bonafos is also mentioned in nos. 1634, 1709, 1932, 2034, 2048, 2122, and 2330. These documents place Crescas in Barcelona at least until 1291. See also Israel Ta-Shma, "Vidal, Crescas," in Encyclopaedia Judaica, 2nd ed., ed. Michael Berenbaum and Fred Skolnik (Detroit: Macmillan, 2007), 20:516.

89. MQp 11, pp. 45-46 / MQd 29, pp. 362-65.

90. Ha-Sulami's letter to Ibn Adret is not included in Minhat kena'ot and does not survive, but ha-Sulami's defense of Levi is clearly indicated by Ibn Adret's response to ha-Sulami, MQp 17, p. 56 / MQd 35, pp. 396-97, 11. 16-25.

91. In addition, while living with ha-Sulami, Levi corresponded personally with Ibn Adret, as we have seen; the exchange was largely respectful (Levi's letter is not preserved, but is known from Ibn Adret's response to it, which is extant in Minhat kena'ot): MQp 16, p. 54 / MQd 34, p. 390, 11. 1-4. 92. This is described by Abba-Mari in the headnote to MQp 17, p. 55 / MQd 35, p. 395, 11. 1-8. 


\title{
Tamar Ron Marvin
}

out of his home. ${ }^{93}$ It was then that Levi found refuge in the Montpellier home of his cousin, the last date and place where he can be located. ${ }^{94}$

Until he received the letters from Bonafos and Ibn Adret, Crescas was not aware of any wrongdoing in Perpignan, he writes; nor did he know of Levi. ${ }^{95}$ These letters of inquiry were not asking about the transgressions of an individual, but more generally about transgressive ideas being passed around the community by darshanim (popular preachers) and teachers. Bonafos merely asks his brother Crescas:

\begin{abstract}
The rabbi Solomon [Ibn Adret], God be with him, pressed me to go on and apprise you of things reaching our ears from those who pass through and return, and also from epistles. It was via letter that he [Ibn Adret] was made aware that there were peoples in the land, from the slopes of [Mount] Amnon inwards, ${ }^{96}$ who denigrated the messengers of God and that which is written in the Torah and Prophets. Upon hearing this, he [Ibn Adret] was upset because of these things, and surprised that you were not among those attempting to correct [the problem]. For this reason I'm writing to you, to determine whether these things really and truly came out of the mouths of those who [supposedly] said them. If it is as they [the reporters] say, who are these people - who is their father, ${ }^{97}$ where are their chastisers? ${ }^{98}$
\end{abstract}

Nowhere does Bonafos imply that he has in mind a single individual who is the source of the problem. Not only does he pose the rhetorical question in the plural-"who are these people?"-but he also seems far more concerned with determining the truth of the rumors heard in Barcelona about some form of extreme allegorizing (such as readings of Scripture that are entirely symbolic

93. Ha-Sulami's words do not survive; this is Abba-Mari's report (in the headnote to MQp 17, p. 55 / MQd 35, p. 395, 11. 1-8).

94. Samuel b. Reuben, the son of Levi's paternal uncle, almost certainly lived in Montpellier. It is commonly assumed that he lived in Béziers, probably due to his name, which, however, is most likely an inherited place-name rather than an indication of where Samuel lived. In his letter to Ibn Adret (MQp 41, pp. 89-93 / MQd 60, pp. 524-37), Samuel b. Reuben constantly references events occurring in Montpellier. The letter is primarily intended as a peacemaking apology for signing with the rationalists - very likely a reference to the missive sent by the Montpellier rationalists to Barcelona (MQp 23, pp. 66-68 / MQd 43, pp. 431-40). Thus it would seem that in the fall of 1304, Levi went to live with Samuel b. Reuben in Montpellier.

95. See below for a detailed discussion of the particulars of Crescas's report.

96. "The land" here is a term referring to Occitania. Medieval Jews, both inhabitants of this region and those addressing its inhabitants, most frequently refer to the region generically as ha-'arez (the land) or 'arezekhem (your land), and as 'erez provinzah - that is, "Provence." See Goss, Gallia Judaica, 489-93; Shlomo Pick, "The Jewish Communities of Provence" (PhD diss., Bar-Ilan University, 1996), 20-28; and Roth, "Regional Boundaries," 72-74. "The slopes of Amnon" constitute the northern boundary of the Land of Israel in the discussion in B. Gittin 8a; here this may be a reference to Montpellier, a city perched on a mountain, as Dimitrovsky suggests: see his note to 1.28 on p. 364 .

97. Lifted from 1 Samuel 10:12.

98. MQp 11, p. 46 / MQd 29, p. 364, 11. 25-32. 
and deny the historicity of biblical narrative). ${ }^{99}$ Moreover, Bonafos seems uncomfortable asking his brother for this information, as though doing so might imply to Crescas that Ibn Adret suspects him of complicity. The warm closing of the letter, more personal than ornamental, suggests a close relationship between the brothers; Bonafos was perhaps more concerned with Crescas's standing in the community than he was with the alleged transgression. While Bonafos's language throughout the letter bespeaks genuine discomfort with potentially transgressive activity in Occitania, he remains skeptical of the information circulating in Barcelona.

Crescas, however, misread the question, apparently mistaking the request for general information about a philosophical movement as a much narrower question about the impropriety of an individual. As a result, he sought out a problematic individual fitting the description in the letters from Barcelona. Once he had asked around, Crescas assumed that, if Bonafos and Ibn Adret were looking for a troublemaker, Levi certainly qualified. ${ }^{100}$ However, Levi was not the only person whom Crescas identified in connection with teaching philosophy to the uninitiated, nor did his report center exclusively around Levi. For instance, Crescas also identified another problematic individual in Montpellier, of whom he wrote:

I still have not been able to lay an eye on this book [the Torah commentary], since its author did not show it to anyone while he was alive. Now his son has decided, after noticing that the text is blurred and almost unreadable, that it must be copied before it is worn out. There is concern that it will be spread around the land. I do not know whether those who informed our lord [about the rationalists] informed him also about this book, or about the youths whose homilies constitute breaches on the subject of Matter and Form, and whom no one protests against. I heard that the scholar N'Astruc de Lunel [Abba-Mari] already informed you of this and of course my lord knows what he replied in this matter, though I have seen neither the question nor the answer.

99. An example of extreme allegorization can be found in another letter by Crescas Vidal, in which he reports on the transgressive ideas contained in a book he had heard about, but did not personally examine: "I can also report to you, my lords, that when I passed through Montpellier, the leader En Todros de Beaucaire told me that one of the philosophizers had written a Torah commentary in the manner of Greek wisdom, and did not include in his commentary an iota of the plain meaning of the Torah, making of everything Matter and Form. From what he [Todros] told me, it reached that point that he [the rationalist commentator] maintained that Armafel and the kings of his coalition imply the four elements - just think what will follow from this" (MQd 12, p. 48 / MQd 30, pp. 370-71, 11. 72-87). King Armafel of Shinar was part of an eastern coalition of four kings that included King Khederlaomer of Eilam, King Tidal of Goim, and King Ariokh of Ellasar, described in Genesis 14. Here Crescas alludes to the complete allegorization of the Torah ("making of everything Matter and Form") and the transmutation of certain prophecies from political foretelling into scientific symbolism. ("Armafel and the kings of his coalition imply the four elements.")

100. Again, this is why Crescas's response to Ibn Adret's initial query, apart from identifying Levi as the provocateur whom Ibn Adret was asking about, was in general nuanced and responsible rather than absolute and alarmist. 


\title{
Tamar Ron Marvin
}

Crescas then turns back to Perpignan, speaking about local darshanim as a group:

\begin{abstract}
Indeed, my lord knows that I have neither seen nor heard anything like this in this, our city, where I have established my dwelling, until now, although two or three times I have heard the sermons preached by the philosophizers in the synagogue while I was there and nothing that they emitted from their mouths was wrongful or blameworthy. I cannot determine whether they restrained themselves in front of me and they are actually of a different mindset, or if their mouths are equal to their minds. ${ }^{101}$
\end{abstract}

If rumors swirled around Levi, they did around others as well, as Crescas dutifully reported. As with his equivocation regarding Levi, Crescas admits that he did not examine the allegedly transgressive Torah commentary himself, and allows that the problematic darshanim might have restrained themselves in his presence. As with Levi, Crescas responsibly maintains that he cannot personally attest to any dangerous ideas being spread in Perpignan.

Though the identification of Levi was not the response the initiators of the controversy sought, neither minded Crescas pointing them to an exemplar of the type of problematic figure Abba-Mari had in mind. Having been made aware of the particulars of Levi's work, Ibn Adret became incensed and condemned Levi in harsh, if measured, terms, as noted above. Levi brought Abba-Mari's anxieties to life for Ibn Adret. Suddenly, the abstract discussion had a name and a face-a villain. Crescas's unsolicited identification of Levi as a popularizer of radical allegory shifted the controversy into high gear.

No more radical or exoteric than others, Levi certainly did popularize allegorical, philosophical interpretations of Scripture, making him a good but inadvertent target. His high social standing, reduced financial situation notwithstanding, meant that Levi was never effectively removed from Jewish society. Levi was primarily charged with promoting dangerous ideas to the young and inexperienced that could lead to nonobservance of Halakhah. However, even his detractors could not agree whether his biggest offense was his personal impropriety or his public teaching. Indeed, they could not quite agree that he was fundamentally transgressive either publicly or privately. Levi's case demonstrates that while exoteric teaching of philosophy was considered to engender a serious threat of ideational transgression, the complexity of developing prosecutory strategies to deal with it rendered such transgression hypothetical in actionable, halakhic terms. Instead, efforts galvanized around a ban that would limit the teaching of philosophy, bypassing the issue of transgression of belief or action altogether. This legislation was never enacted in the south of France, where it was first sought, due to the disruptions of the French expulsions, and enacted but never enforced in Barcelona. Levi was never excommunicated or formally charged in any way.

101. MQd 12, p. 48 / MQd 30, pp. 370-71, 11. 74-87. 
What does Levi's story say about the conceptualization of "heretical" or ideational transgression in medieval Judaism? It demonstrates that for traditionalist Jews, such transgression was primarily a potential threat, consisting of revealing exoterically - through teaching, preaching, or publication - the tools of reason, which could be wielded to reach erroneous conclusions about revealed knowledge. Potentially transgressive beliefs did not inhere in the one who held them, rendering this individual a transgressor. Rather, the rational method by which an individual arrived at such ideas was problematic, and providing access to it indiscriminately was an offense best protected against by a ban of excommunication.

Levi's situation also shows that accusations surrounding ideational transgression were an extraordinarily serious matter not imposed without garnering great scrutiny. As maligned as he was, Levi was defended by prominent members of the community and deferred to even by Ibn Adret. Even at their most serious, the allegations did not imperil Levi's life. The eventual bans - toothless, it would turn out — addressed philosophical study generally, never confronting Levi's teaching personally or directly. The potential for ideational transgression may have been powerful enough a force to drag a Barcelona authority into the affairs of Occitania, but it was not sufficiently dangerous to warrant a blanket ban on philosophy, nor to punish Levi, or anyone else, on an individual level. Even the finger pointed at Levi was incidental, the result of Crescas Vidal's misunderstanding of his brother's more general inquiry about philosophical activity in Perpignan. There is every indication that, for someone who was singled out by the leading figure of the time, Levi was able to continue to live more or less as before, never subject to any kind of communal censure or harassment. After about the midpoint of the communal debate, Levi goes unmentioned. There were, in the end, no heresies or heretics in medieval Jewish Occitania — only seductive ideas and reckless teachers. 